\title{
Daily Variations in Protein and Energy Metabolism During the Day in Hair Sheep in the Ecuadorian Amazon Region
}

\author{
Moyano $\mathrm{JC}^{1,2^{*}}$, López $\mathrm{JC}^{1,2}$, Galván Doria $\mathrm{C}^{3}$, Marini $\mathbf{P R}^{4,5}$ and Fischman $\mathbf{M L}^{2,4}$ \\ ${ }^{1}$ Center for Research, Amazon State University, Ecuador \\ ${ }^{2}$ Faculty of Veterinary Medicine and Zootechnics, University of Córdoba, Colombia \\ ${ }^{3}$ Faculty of Veterinary Sciences, National University of Rosario, Argentina \\ ${ }^{4}$ Faculty of Veterinary Sciences, Laboratory of Spermatic Quality and Cryopreservation of Gametes, University of Buenos Aires, Buenos Aires, Argentina \\ ${ }^{5}$ Faculty of Veterinary Sciences, Institute of Research and Technology in Animal Reproduction (INITRA), University of Buenos Aires, Buenos Aires, Argentina
}

*Corresponding author: Moyano JC, Postgraduate and Amazon Conservation, Center for Research, Amazon State University, Ecuador, Tel: +593984182598; E-mail: juancamt@hotmail.com

Rec date: March 23, 2018; Acc date: March 30, 2018; Pub date: March 31, 2018

Copyright: ( 2018 Moyano JC, et al. This is an open-access article distributed under the terms of the Creative Commons Attribution License, which permits unrestricted use, distribution, and reproduction in any medium, provided the original author and source are credited.

\begin{abstract}
The objective of this study was to determine and evaluate the protein and energy metabolism at different times of the day in Blackbelly $x$ Pelibuey hair sheep during the rearing stage. The animals were under free grazing conditions in the Ecuadorian Amazon Region. We studied 9 ewes belonging to the flock of the Centre for Research, Postgraduate Studies and Conservation of Amazonian Biodiversity. They were reared under the same environmental, nutritional and management conditions. Serial samples were taken over 3 consecutive days at different times. A significant difference $(p \leq 0.5)$ was observed between the sampling days for glucose, urea and total proteins. In the sampling schedule, significant differences were found $(p \leq 0.5)$ for glucose. It can be concluded that both the day and the time of sampling affect the concentrations of protein and energy metabolites in Blackbelly $x$ Pelibuey ewes reared under free grazing conditions in the Ecuadorian Amazon Region.
\end{abstract}

Keywords: Sheep; Rearing; Protein; Energy; Metabolic profile

\section{Introduction}

The growing demand for food in today's world and the need to achieve sustainability in livestock production leads to the need for an adequate animal production system. The main criterion is the type of available food, with the aim of achieving greater food efficiency by employing a maximum use of existing local resources. Likewise, it is essential that producers dominate and apply new technologies and innovations to production systems according to the needs of each system, thus achieving greater productivity and efficiency [1].

Metabolic profiles were designed in order for one to study the imbalances that may occur between input, bio-transformation and output of elements into the organism [2]. This helps one find out about and diagnose the nature of metabolic disorders and thus allows one to avoid or correct adverse situations that can generate large productive losses in a herd [3].

One way to specify the planning of food management on a sheep farm is through nutritional monitoring of the herd, which is partly based on the use of metabolic profiles around critical nutritious periods. The values obtained in the biochemical parameters measured through this monitoring could give an approximation of nutritional balance, leading one to be able to take corrective measures in a timely manner [4]. Energy level is represented by blood glucose levels. Amongst the blood metabolites that best represent protein metabolism are total proteins, urea and albumin [5], given that blood proteins are synthesised mainly in the liver and that their rate of synthesis is directly related to the nutritional status of the animal.
In the Ecuadorian Amazon Region, the use of metabolic profiles in sheep during the rearing stage is rare, both in the productive and research sectors, which means that there is little or no information about said profiles. The objective of this study was to determine and evaluate the protein and energy metabolism at different times of the day in Blackbelly $\mathrm{x}$ Pelibuey (F1) ewes during the rearing stage and under free grazing conditions in the Ecuadorian Amazon Region.

\section{Materials and Methods}

We studied 9 Blackbelly x Pelibuey (F1) ewes with an average age of 5 months, an average weight of $15 \mathrm{~kg}$ and managed under extensive grazing. The sheep belong to the flock of the Centre for Research, Postgraduate Studies and Conservation of Amazonian Biodiversity (CIPCA), which is located in the Arosemena Tola canton of the province of Napo (Ecuador), $44 \mathrm{~km}$ along the road between Puyo and Tena (coordinates: S $01^{\circ} 14.325^{\prime}$; W077 $\left.{ }^{\circ} 53.134^{\prime}\right)$. The climate of the area is tropical with an average annual rainfall of $4000 \mathrm{~mm}$, an average relative humidity of $80 \%$, temperatures that range between 15 and $25^{\circ} \mathrm{C}$ and an altitude that varies between 580 and 990 metres above sea level. Its topography is characterised by slightly undulating reliefs, without steep slopes, distributed amongst natural plateaus of great extension. Although the soils have a very heterogeneous composition, most originate in fluvial sediments from the Andean region of the country [6].

The sheep remained in pasture from 7:00 am to 4:00 pm and in a barn during the night with a constant supply of water. The predominant grasses include Brachiaria grass (Brachiaria decumbens) (17.585 kg DM/ha/year, Protein: 10.6\%, Phosphorus: 0.18\%, DIV: 44.4\%); Brizantha (Brachiaria brizantha) $(26,970 \mathrm{~kg} \mathrm{DM} / \mathrm{ha} / \mathrm{year}$, 
Page 2 of 3

Protein: 10.1\%, Phosphorus: 0.18\%, DIV: 44.1\%); Forage peanut (Arachis pintoi) $(6,212 \mathrm{~kg} \mathrm{DM} / \mathrm{ha} /$ year, Protein: 19.4\%, Phosphorus: 0.21\%, DIV: 59.2\%); Desmodium (Desmodium ovalifolium) $(5,890 \mathrm{~kg}$ DM/ha/year, Protein: $16.3 \%$, Phosphorus: $0.16 \%$, DIV: $39.6 \%)$ and Brazilian alfalfa (Stylosanthes guianensis) (15,237 kg DM/ha/year, Protein: 21.4\%, Phosphorus: 0.4\%, DIV: 48.7\%) [7-9].

The sanitary management habitually used for the CIPCA sheep herd was applied. This includes deworming, baths against ticks and flies and vaccinations for foot and mouth disease, bovine rabies and vesicular stomatitis.

Serial samples were taken over three consecutive days in April 2017 at different times: 7:00 am, 9:30 am, 11:30 am and 1:30 pm. From each animal, $5 \mathrm{ml}$ of blood was taken by venipuncture in the coccygeal vein using anticoagulant-free vacuum tubes (BD Vacutainer ${ }^{\circledR}$ red cap). After that, the blood samples were centrifuged $(3,000 \mathrm{rpm}$, for $30 \mathrm{~min})$ to separate out the serum, which was stored at $-20^{\circ} \mathrm{C}$ until processing. The variables measured were Glucose, Urea, Creatinine and Total Proteins.

The Glucose, Urea, Creatinine and Total Protein determinations were made by molecular spectrophotometry (Thermo Scientific, Series GENESYS $10 \mathrm{UV}$, Waltham, Massachusetts, USA), using HUMAN ${ }^{\circledR}$ diagnostic kits (Gesellschaft für Biochemicand Diagnostica mbH).

The kit for glucose determination is based on the GOD-PAP method using the colorimetric enzymatic test without deproteinisation of the sample. The Urea dosing kit uses the modified Berthelot method, colorimetric enzymatic analysis. The Creatinine is based on the Jaffé Reaction, colorimetric test for kinetic measurements, which does not require deproteinisation. As for the kit for total protein determination, it is a colorimetric test based on the Biuret method.

The data obtained were organised and tabulated for subsequent analysis by means of descriptive statistics to determine mean and standard error. The differences between the means were subjected to an analysis of variance with the criterion of classification and also to HSD multiple comparison tests of Turkey-Kramer HSD ( $p \leq 0.05)$. All statistical analyses were performed using the JMP programme, version 5.0 for Windows $\left(\mathrm{JMP}^{\circledast}, 2003\right)$.

\section{Results and Discussion}

\section{Glucose}

The means per day and per sampling hour are within the normal range, however, they are close to the lower limit of $44-81.2 \mathrm{mg} / \mathrm{dl}$ [10]. The blood glucose concentration found in the analysed ewes was 52.9 $\pm 5.1 \mathrm{mg} / \mathrm{dl}$, which is below the reported concentrations [11], in pregnant ewes $(62.2 \pm 11.8 \mathrm{mg} / \mathrm{dl})$, in non-pregnant hair sheep $(75.6 \pm$ $27.5 \mathrm{mg} / \mathrm{dl})$ [12], in the Creole sheep breed Serrana Lanada [13] (83.9 $\pm 37.6 \mathrm{mg} / \mathrm{dl})$ and in non-pregnant Tsigai ewes [14] $(69.6 \pm 5.8 \mathrm{mg} / \mathrm{dl})$ and higher than those reported by Tabeleão et al. [15] in young sheep supplemented with the Ille and Corriedale breeds $(31.5 \mathrm{mg} / \mathrm{dl})$. These low blood glucose levels may indicate a low energy intake in the ingested forages, what would result in the females not gaining weight on a daily basis which is necessary in order to be put to service for the first time (Table 1).

\begin{tabular}{|l|l|l|l|}
\hline Day & Mean \pm SE & Time & Mean \pm SE \\
\hline 1 & $57.4 \pm 2.3 \mathrm{a}$ & $07: 30$ & $59.2 \pm 2.6 \mathrm{a}$ \\
\hline
\end{tabular}

\begin{tabular}{|l|l|l|l|}
\hline 2 & $54.1 \pm 1.8 \mathrm{a}$ & $09: 30$ & $53.0 \pm 2.3 \mathrm{ab}$ \\
\hline 3 & $47.4 \pm 1.2 \mathrm{~b}$ & $11: 30$ & $49.7 \pm 2.0 \mathrm{~b}$ \\
\hline & & $13: 30$ & $49.8 \pm 1.2 \mathrm{~b}$ \\
\hline
\end{tabular}

Note: Different letters in each column indicate significant differences $p \leq 0.05$.

Table 1: Blood glucose values in sheep according to day and time of sampling $(\mathrm{mg} / \mathrm{dl})$.

\section{Protein profile}

The average values of total proteins found in this study are summarised in Table 2. The values are within the normal values [10]: 5.9-7.8 g/dl. A significant difference ( $\mathrm{p} \leq 0.5)$ was observed between days, but not between sampling times $(p \geq 0.5)$. The mean found for the concentration of total proteins was $6.7 \pm 0.3 \mathrm{~g} / \mathrm{dl}$, which is similar to those in ewes $(6.9 \mathrm{~g} / \mathrm{dl})$ [13], lower than those found in nonpregnant hair sheep $(8.5 \pm 2.8 \mathrm{~g} / \mathrm{dl})[12]$ and higher than those found, in pregnant ewes $(3.6 \pm 1.3 \mathrm{~g} / \mathrm{dl})$ [16], in pregnant ewes $(5.8 \pm 0.1 \mathrm{~g} / \mathrm{dl})$ [11] and in ewes at the end of gestation $(3.3 \pm 1.1 \mathrm{~g} / \mathrm{dl})$ [17]. This fact may be related to the physiological state of the animals in this study, since they are sheep in an active growth stage, influenced by both growth hormones and sexual hormones, which act as powerful anabolics, especially in the muscles, stimulating the uptake of amino acids and protein synthesis and in turn inhibiting proteolysis [18].

\begin{tabular}{|l|l|l|l|}
\hline Day & Mean \pm SE & Time & Mean \pm SE \\
\hline 1 & $7.0 \pm 0.1 \mathrm{a}$ & $07: 30$ & $6.7 \pm 0.1 \mathrm{a}$ \\
\hline 2 & $6.7 \pm 0.1 \mathrm{ab}$ & $09: 30$ & $6.6 \pm 0.1 \mathrm{a}$ \\
\hline 3 & $6.5 \pm 0.1 \mathrm{~b}$ & $11: 30$ & $6.8 \pm 0.1 \mathrm{a}$ \\
\hline & & $13: 30$ & $6.6 \pm 0.1 \mathrm{a}$ \\
\hline
\end{tabular}

Note: Different letters in each column indicate significant differences $p \leq 0.05$.

Table 2: Total protein values in sheep according to day and time of sampling $(\mathrm{g} / \mathrm{dl})$.

\section{Urea}

Table 3 shows the average values obtained for urea over the three days and at different sampling times; a significant difference was found ( $\mathrm{p} \leq 0.5$ ) between days, but not between sampling times $(\mathrm{p} \geq 0.5)$. The average value per day and per sampling time was $32.3 \pm 4.6 \mathrm{mg} / \mathrm{dl}$, which is above the normal values for this metabolite $(10.3-24.6 \mathrm{mg} / \mathrm{dl})$ [10]. When compared to other studies, the mean found for the concentration of urea was similar to those reported by Moris [11], in gestating female hair sheep $(32.5 \pm 15.8 \mathrm{mg} / \mathrm{dl})$ and above those recorded in Santa Ines sheep $(26.7 \pm 2.2 \mathrm{mg} / \mathrm{dl})$ in grazing systems [19]. The values found in this study indicate a balance in the protein. Although the individuals studied have a low protein diet and consume forages with high fibre contents, the protein balance does not seem to have been affected.

\begin{tabular}{|l|l|l|l|}
\hline Day & Mean \pm SE & Time & Mean \pm SE \\
\hline 1 & $37.4 \pm 1.5 \mathrm{a}$ & $07: 30$ & $35.0 \pm 2.0 \mathrm{a}$ \\
\hline 2 & $31.2 \pm 0.9 \mathrm{~b}$ & $09: 30$ & $31.4 \pm 1.4 \mathrm{a}$ \\
\hline
\end{tabular}




\begin{tabular}{|l|l|l|l|}
\hline 3 & $28.3 \pm 1.1 \mathrm{~b}$ & $11: 30$ & $31.6 \pm 1.1 \mathrm{a}$ \\
\hline & & $13: 30$ & $31.2 \pm 1.4 \mathrm{a}$ \\
\hline
\end{tabular}

Note: Different letters in each column indicate significant differences $p \leq 0.05$

Table 3: Values of blood urea in sheep according to day and time of sampling $(\mathrm{mg} / \mathrm{dl})$.

\section{Creatinine}

The creatinine values obtained in this study are shown in Table 4. No significant difference ( $\mathrm{p} \geq 0.5$ ) was found for these values according to day or time of sampling. The mean for the creatinine concentration was $2.3 \pm 0.1 \mathrm{mg} / \mathrm{dl}$, which is above the normal values $(0.9-2.0 \mathrm{mg} / \mathrm{dl})$ [10] but similar to those $(2.2 \pm 0.2 \mathrm{mg} / \mathrm{dl})$ [20]. It is advisable to estimate the concentration of creatinine in conjunction with that of urea, or when an increase in the urea level is found. An increase in creatinine alongside anormal urea value can occur in animals with decreased renal functionality receiving low protein diets (1.2-1.9 $\mathrm{mg} / \mathrm{dl})[21]$.

\begin{tabular}{|l|l|l|l|}
\hline Day & Mean \pm SE & Time & Mean \pm SE \\
\hline 1 & $2.3 \pm 0.1 \mathrm{a}$ & $07: 30$ & $2.2 \pm 0.1 \mathrm{a}$ \\
\hline 2 & $2.4 \pm 0.1 \mathrm{a}$ & $09: 30$ & $2.0 \pm 0.1 \mathrm{a}$ \\
\hline 3 & $2.2 \pm 0.1 \mathrm{a}$ & $11: 30$ & $2.5 \pm 0.1 \mathrm{a}$ \\
\hline & & $13: 30$ & $2.5 \pm 0.1 \mathrm{a}$ \\
\hline
\end{tabular}

Note: Different letters in each column indicate significant differences $p \leq 0.05$.

Table 4: Serum creatinine values in sheep according to day and time of sampling $(\mathrm{mg} / \mathrm{dl})$.

\section{Conclusion}

Of the metabolites studied, the greatest variations occurred in glucose according to day and time of sampling. The total proteins and urea, although they presented significant differences between days, were not affected by time of sampling. Creatinine did not present significant differences between days or between sampling times, thus was the most stable parameter.

This research provides some reference values, which are so far nonexistent to the best of our knowledge. These values could be used to compare the productivity and adaptation of small ruminants in the Amazonian environment, allowing one in turn to take corrective measures if necessary.

\section{References}

1. Bernales DB (1998) Characterization of the energetic and protein metabolic balance in the sheep milking period Latxa Cara Rubia a pastoreo [grade work]. Austral University of Chile.

2. Rowlands GJ, Payne JM, Dew SM, Manston R (1973) A potential use of metabolic profiles in the selection of superior cattle. Vet Rec 93: 48-49.

3. Payne JM, Sally M, Manston R, Faulks M (1970) The use of metabolic profile test in a dairy herds. Vet Rec 87: 150-158.
4. del Valle J, Wittwer F, Hervé M (1983) Study of the metabolic profiles during the gestation and lactation periods in romney sheep. Arch Med Vet 15: 23 .

5. Batista K (2007) Metabolic profile of grazing lambs submitted to different environments and food supplements in semi-arid Paraiba. Patos, BF: Federal University of Campina Grande Rural Health and Technology Center.

6. Torres V (2016) Diversity, structure and concentration of carbon in an evergreen piedmont forest from 800 to 900 meters above sea level, in the Ecuadorian Amazon. Research project prior to obtaining the Master's Degree in Forest Management and Use.

7. Gonzáles R, Anzules A, Cera A, Riera L (1997) Manual of pastures for the Ecuadorian Amazon. National Institute of Agricultural Research (INIAP), p: 66.

8. National Autonomous Institute of Agricultural Research (INIAP) (1997) Manual of tropical pastures for the Ecuadorian Amazon. Manual No 33, Guayaquil.

9. Leonard I (2015) Native forage resources and promising for livestock in the province of Pastaza. Challenges and possibilities for a sustainable livestock in the province of Pastaza of the Ecuadorian Amazon. State University of the Amazon, Puyo, Capítulo IV, pp: 46-69.

10. Kaneko JJ, Harvey JW, Bruss ML (1997) Appendix. In: Clinical Biochemistry of domestic animals. 5th edn. Academics Press, pp: 885-905.

11. Moris de JB, Libardo AM, Clara CR, Juan CS, Rene PM, et al. (2016) Determination of the Metabolic Profile During the PregnancyBreastfeeding Period in Ovine Hair Females in Córdoba. Colombia Journal of the Faculty of Veterinary Sciences 57: 114-124.

12. Doria CG, Pinto CR, Garay OV (2014) Variation of serum glucose and protein concentrations during the day in different sexes. Rev Med Vet 28 : 57-66.

13. Couto A (2010) Genetic characterization and hematological and biochemical profile in criolol domesticated sheep of the Santa Catarina highland plateau Santa Catarina, Brazil. Doctoral Thesis, Faculty of Veterinary Science, University of Leon, Spain.

14. Antunovic Z, Novosele J, Sauerwein H, Speranda M, Vegara M, et al. (2011) Blood metabolic profile and some of hormones concentration in ewes during different physiological status. Bul J Agric Sci 17: 687-695.

15. Tabeleão V, Del Pino F, Goulart M, Schwegler E, Moura SV, et al. (2008) Influence of monensin and levedura on ruminal and metabolic parameters in semiconfined cordeiros. Acta Sci Anim Sci 30: 181-186.

16. Ríos C, Moreira R, Castro N (2010) Effects of supplementary feeding on some biochemical variables in sheep and sheep of the Magallanes area, Chile, 2007. University Santo Tomás, Santiago, Chile.

17. Moghaddam GH, Olfati A (2012) Metabolic profiles in crossbreed ewes in late pregnancy. In: Proceedings of the 15th AAAP Animal Science Congress, Thailand, pp: 2208-2209.

18. Cal-Pereyra L, Benech A, Da Silva S, Martín A, González-Montaña JR (2011) Energy metabolism in shorn and unshindered pregnant sheep subjected to two nutritional levels. Effect on the energy reserves of their lambs. Arch Med Vet 43: 277-285.

19. Santos RA, Campos AGS, Afonso JAB, Soarese PC, Mendonça CL (2012) Effect of the administration of propylene glycol and cobalt associated with vitamin B12 on the metabolic profile and enzymatic activity of Santa Inês sheep in the peripartum. Pesq Vet Bras 32: 60-66.

20. Castañeda A (2010) Importance of metabolites such as: glucose, total proteins, triglycerides, urea and creatinine in two treatments T1: pregnant sheep and T2: calving.

21. Kaneko JJ (1980) Clinical Biochemistry of Domestic Animals. 3rd edn. 